\title{
Experimental Study the Effect of Additional Flat Plate Reflector to Performance the Sinusoidal Solar Water Heater
}

\author{
Dedy Ashari ${ }^{1}$, Djatmiko Ichsani ${ }^{1}$
}

\begin{abstract}
New Renewable Energy is currently not fully utilized. Energy sourced from the sun is one of the most exploited energy sources today in several countries in the world, which in large scale has been used as a power plant. The solar collector is a heat exchange device that serves to convert solar radiation energy into a form of heat energy to heat a working fluid, such as water and air. Various methods have been undertaken to improve the performance of solar collectors, including using flat plate reflectors. Reflectors are used to reflect the diffused sunlight to focus on solar cells and ultimately increase the value of solar cell output power. Experimental studies in this study were conducted to see the performance of a solar collector sinusoidal with and without the addition of reflectors under varying discharge conditions. Variations of mass flow rate in this study were 18 and 20 liters/hour. The reflector angle on the solar collector is set at $40^{\circ}$ on both sides of the reflector. From this study, the results for the efficiency of a solar collector with the addition of a reflector are the highest at $43,91 \%$ at a mass flow rate of 20 liters / hour.
\end{abstract}

Keywords_-Solar Collector, Water Heater, Sinusoidal, Reflector, Intensity of Solar Radiation

\section{INTRODUCTION}

E lectricity is one of the main needed by humans around the world. At this time, the source of electrical energy is mostly derived from fossil energy such as petroleum and coal which is a type of non-renewable energy or energy source that can't be renewed, which in the future will be exhausted. So the solution that can be used is to use other renewable energy sources or so-called renewable energy that comes from water, wind or sunlight. The solar collector is a heat exchange device that serves to convert solar radiation energy into a form of heat energy to heat a working fluid, such as water and air. Solar Water Heater (SWH) has proven to be an effective technology to convert solar energy into heat energy. Solar Water Heater (SWH) has been widely used around the world due to its economical and simple system [1]. The conversion efficiency of solar heat is around $70 \%$ when compared to the direct conversion of electricity from the sun which has an efficiency of only about $17 \%$ [2]. SWH can be classified into several types, including passive SWH and active SWH. In passive $\mathrm{SWH}$, cold water in the $\mathrm{SWH}$ absorber tubes gets heated due to solar radiation and rises to the top and the cold water takes the place of hot water and the cycle continues until the temperature of the water equalized. Active SWH uses external source like pump for water circulation in the system [3].

Flat plate reflector in the solar collector serves to reflect solar radiation towards the collector, so that it can increase the amount of solar energy that can be received by the collector [4].

\footnotetext{
${ }^{1}$ Dedy Ashari and Djatmiko Ichsani are with Department of Mechanical Engineering, Institut Teknologi Sepuluh Nopember, Surabaya, 60111, Indonesia.E-mail: dedyashari89@gmail.com; djatmiko@me.its.ac.id.
}

[5] Theoretical analysis of research on solar collectors with flat plate reflectors has been done before. He predicts that solar radiation absorbed by collectors throughout the year is greatly influenced by the tilt angle of the collector and reflector. [6] Conducted a study on the effect of adding a V-reflector on a solar water heater (SWH), the results of his research showed that the addition of a V-reflector can improve the performance of the solar water heater. Research on determining the position of collector solar on the total heat energy produced by solar collectors is also done by [7]. The flat plate reflector is made of aluminum with the same dimensions as the dimensions of the flat plate solar collector. The solar collector is installed with an angle of $\beta=45^{\circ}$. The results showed that the addition of a flat plate reflector at optimal position $45^{\circ}$ collector solar can increase the amount of heat energy produced by solar collector around $35-44 \%$ in the summer period (June September) compared to without using a reflector.

[8] Conducted research on the addition of reflectors that can be adjusted to tilt angles on both the left and right sides of the solar water heater collector to improve efficiency. The reflector tilt angle is determined at $60^{\circ}$ for the left side and $30^{\circ}$ for the right side, can be seen in Figure 1. The slope of the solar collector is $\beta=45^{\circ}$, and the mass flow rate is 0.1 and 0.2 liters / minute. From the study, the maximum efficiency of the collector was recorded without using a reflector of around $51 \%$, while the addition of the reflector efficiency was $61 \%$. It can be seen that the addition of a reflector to a solar collector can increase efficiency by $10 \%$.

In this study the reflector is made of flat mirrors, using solar radiation reflections from the reflector is expected to increase heat reception in the absorber. This research will be focused on increasing the efficiency of heat transfer in 
the water heater solar collector by adding a reflector with a certain tilt angle to the surface of the solar collector.

\section{METHOD}

\section{A. Experimental Set-up}

This solar collector is made in the Solar Energy Engineering Laboratory of ITS Surabaya. The location for this research is on the third floor rooftop of the laboratory with outdoor temperatures of around $38^{\circ} \mathrm{C}$. The ITS campus is in coordinates $7^{\circ} 16$ ' $\mathrm{LU}$ - $112^{\circ} 43^{\prime} \mathrm{BT} / 7,267^{\circ} \mathrm{LS}$ $112,717^{\circ} \mathrm{BT}$. The time of data collection for this study is in July 2018, starting from 9am to 3pm. Experiments in this study on a solar water heater collector using sinusoidal absorber plates with the addition of a flat plate reflector on both sides of the solar collector.

The dimensions of the solar collector are $1220 \mathrm{~mm}$ long, $520 \mathrm{~mm}$ wide and $35 \mathrm{~mm}$ high which consists of three main parts: absorber and the header on the inlet and outlet parts. The dimensions of the absorber are $920 \times 500 \mathrm{~mm}$, for the size of the header width in the inlet and outlet section each is $140 \mathrm{~mm}$ from the end of the absorber to the gate valve which serves as a water entry point for the solar collector. In this experiment using two different of mass flow rates, 18 and 20 liters / hour. and for the angle of the reflector determined by $40^{\circ}$, can be seen in Figure 3 .

This water heater solar collector uses a sinusoidal absorber plate, with the dimensions of the solar collector is $1220 \mathrm{~mm}$ long, $520 \mathrm{~mm}$ wide and $35 \mathrm{~mm}$ high consisting of three main parts, absorber and header on the inlet and outlet. The dimension of its own absorber is 920 x $500 \mathrm{~mm}$, for the width of the header on the inlet and outlet respectively is $140 \mathrm{~mm}$ from the end of the absorber to the gate valve hole which functions to regulate the inlet and out water of the solar collector. In this experiment using different water discharge, which is 18 and 20 liters/hour. As for the slope of the reflector is determined by $40^{\circ}$.

\section{B. Experimental Data}

The heat energy from sun is converted into thermal energy of water in the collector [8] as

$$
\mathrm{Q}_{\mathrm{u}}=\dot{\mathrm{m}} \mathrm{C}_{\mathrm{p}}(\Delta \mathrm{T})=\dot{\mathrm{m}} \mathrm{C}_{\mathrm{p}}\left(\mathrm{T}_{\text {out }}-\mathrm{T}_{\text {in }}\right)
$$

Solar collector efficiency can be determined as

$$
\eta=Q_{u} / A_{c} I
$$

Where $A_{c}$ is collector area and $I$ is radiation intensity.

\section{RESUlT AND DISCUSSION}

\section{A. Radiation Intensity}

The collector scheme with the addition of reflectors on both sides of the collector can be seen in Figure 2. The effect of adding a reflector to a solar collector can be seen in Figure 5. which can be seen if the radiation intensity value is greater when compared without using a reflector. With the increase in radiation intensity received by the collector will affect the value of $\mathrm{Q}_{\mathrm{u}}$. This is caused by the increasing intensity of solar radiation from the reflector leading to the absorber which causes the absorber temperature to be higher than before.

\section{B. Useful Energy (Quse)}

Research carried out for two variations of mass flow rates obtained results as can be seen in table 1 , the high flow rate of mass flowing in the absorber makes the $\mathrm{Q}_{\mathrm{u}}$ value produced higher than the smaller mass flow rate under conditions with the addition of a reflector. This condition is different without the addition of a reflector, where a smaller mass flow rate will cause a higher $\mathrm{Q}_{\mathrm{u}}$ value compared to a larger mass flow rate. This happens because the $\mathrm{Q}_{u}$ value generated is related to temperature and the mass flow rate that passes through the absorber. With the increasing exit temperature produced, the Qloss that occurs is smaller, because of the smaller coefficient of convection between the absorber and the cover glass. The highest $\mathrm{Q}_{\mathrm{u}}$ value is 197,682 watts at $11: 00$ at the condition of a mass flow rate of 20 liters / hour with the addition of a reflector.

\section{Efficiency of solar collectors}

Addition of reflector has an effect on increasing the collector efficiency. Figure 7 shows the efficiency value that continues to increase along with the increase in mass flow rate. The test results can be seen in Table 1 . where the highest efficiency is $43,91 \%$ at a mass flow rate of 20 liters / hour with the addition of a reflector. The efficiency value is directly proportional to the value of $\mathrm{Q}_{u}$ and inversely proportional to the intensity of radiation. The high intensity of solar radiation will make the $\mathrm{Q}_{\mathrm{u}}$ value large, so the resulting efficiency will be higher when the radiation intensity is low.

\section{CONCLUSION}

From the research that has been done on the solar collector with the addition of reflector obtained the following conclusion.

Adding a flat plate reflector to the collector can increase the intensity of solar radiation received by solar collectors which can increase the efficiency of the solar collector.

Changes in the mass flow rate on the fluid affect the $\mathrm{Q}_{\mathrm{u}}$ value and also the efficiency of the solar collector. In conditions without the addition of a reflector, a smaller mass flow rate has a $Q_{u}$ value and high efficiency compared to a larger mass flow rate, because the convection coefficient that occurs is a small value which causes the Qloss value to be small so that it can increase efficiency.

In conditions with the addition of a reflector, the intensity of solar radiation to the collector will increase. But in the condition of the same mass flow rate with conditions without the addition of a reflector, the efficiency value is not too increased because the intensity of the sun is large, the convection coefficient that occurs is also greater, so that efficiency does not increase too much. The efficiency value will increase at a higher flow rate condition because the higher the mass flow rate, will increase the $Q_{u}$ value and will increase the collector's efficiency value.

Reducing the value of the convection coefficient in the collector, such as by making the area between the absorber and the glass cover into a vacuum, is expected to increase the efficiency of the solar collector. 


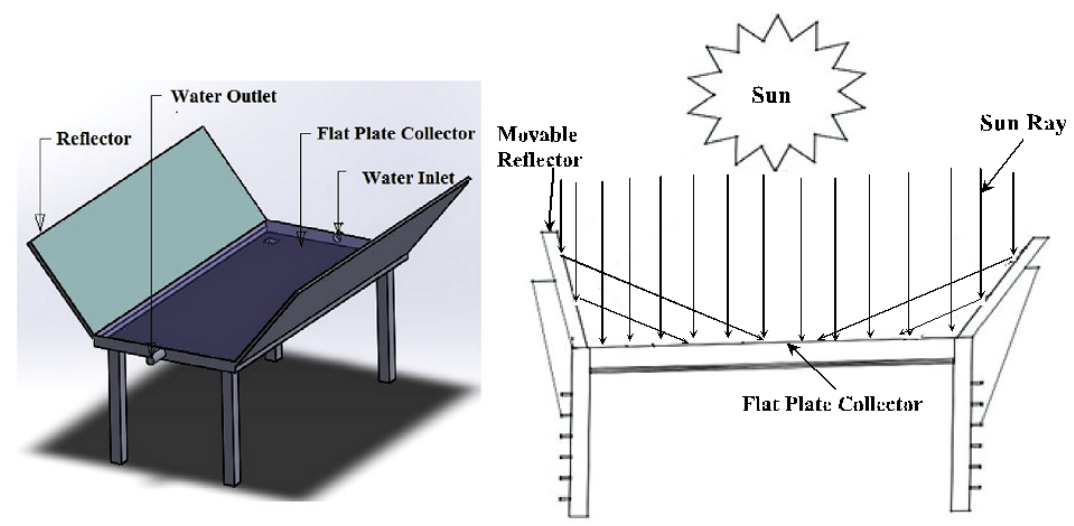

Figure 1. Scheme of flat plate collector with the addition of reflector (Bhomwik,2017)

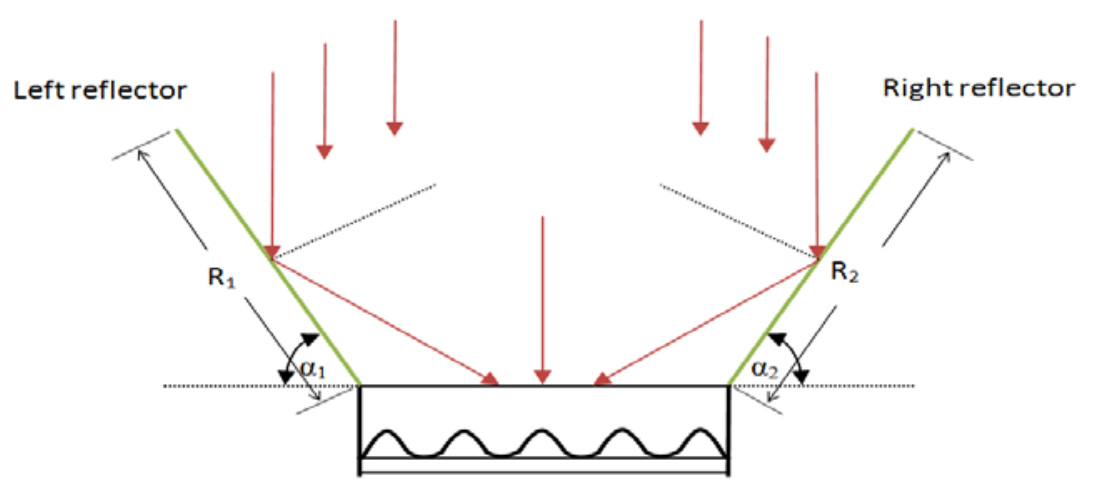

Figure 2. Scheme of solar collector sinusoidal with the addition of reflector.

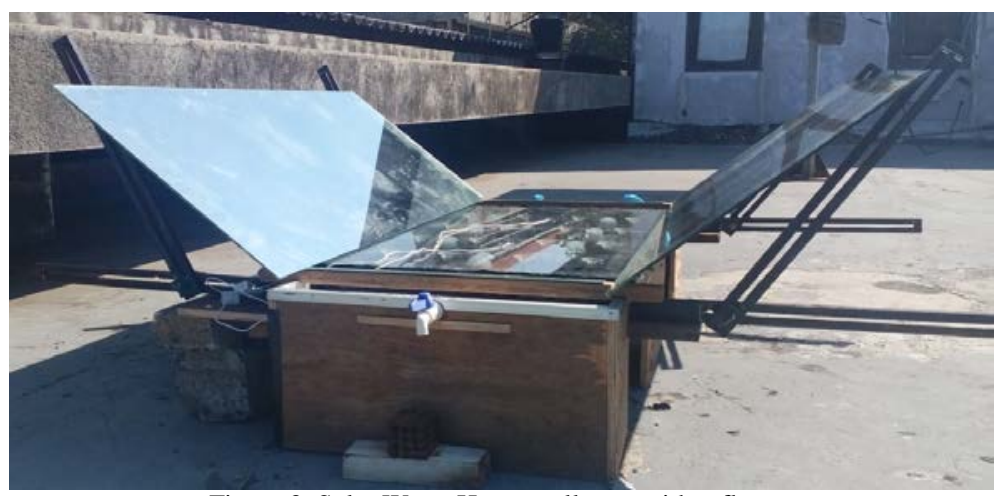

Figure 3. Solar Water Heater collector with reflector

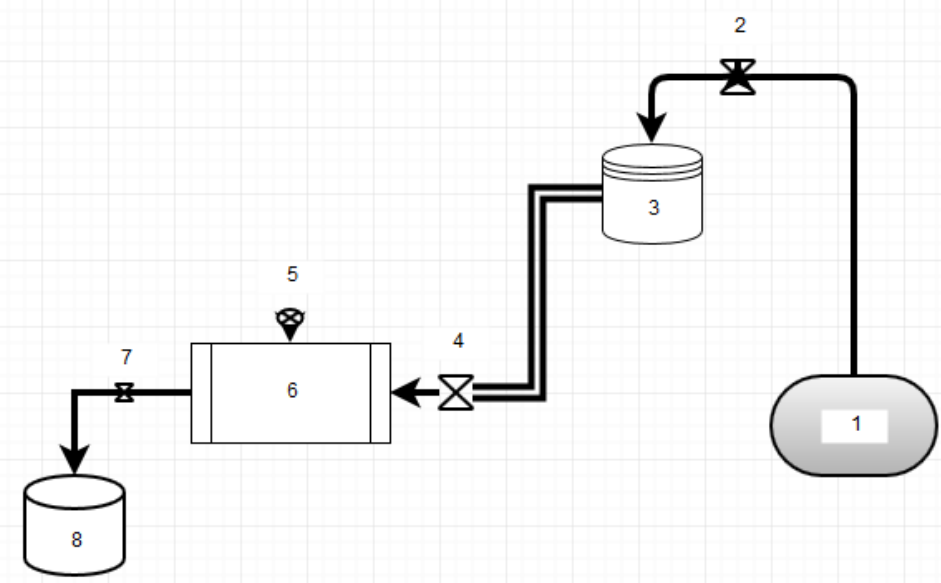

Figure 4. Installation scheme of Solar Water Heater. (1) Pump, (2) Reservoir valve, (3) Reservoir, (4) Inlet valve, (5) Digital Thermometer, (6) Solar collector, (7) Outlet valve, (8) Water reservoir. 


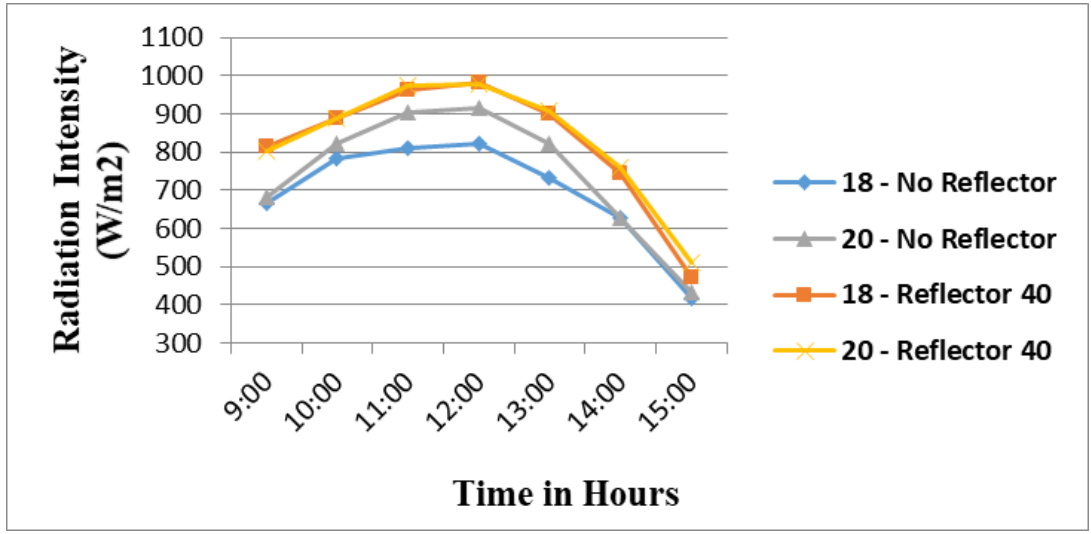

Figure 5. Radiation intensity with and without reflector.

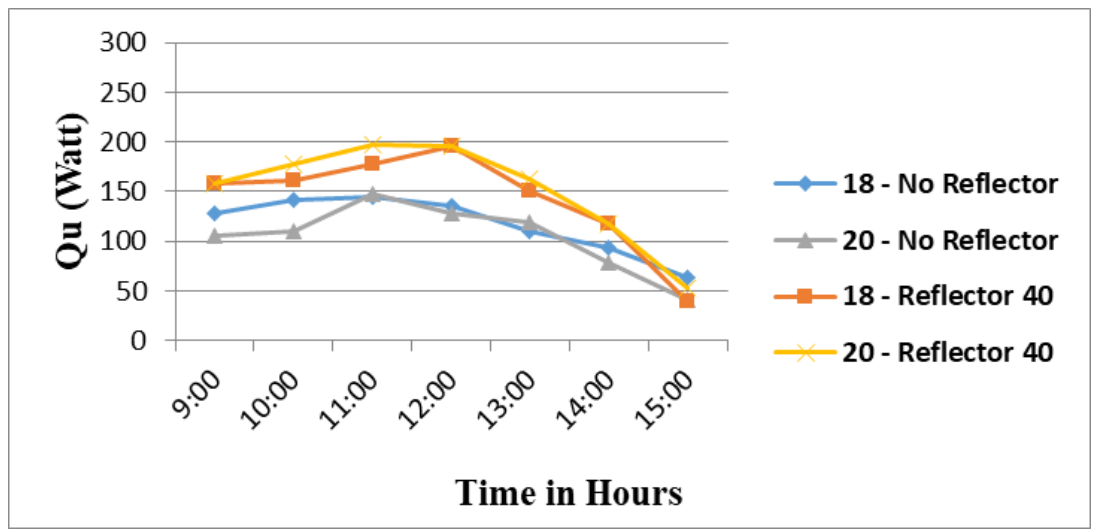

Figure 6. Quse with variation of flow rate 18 and 20 litres/hour

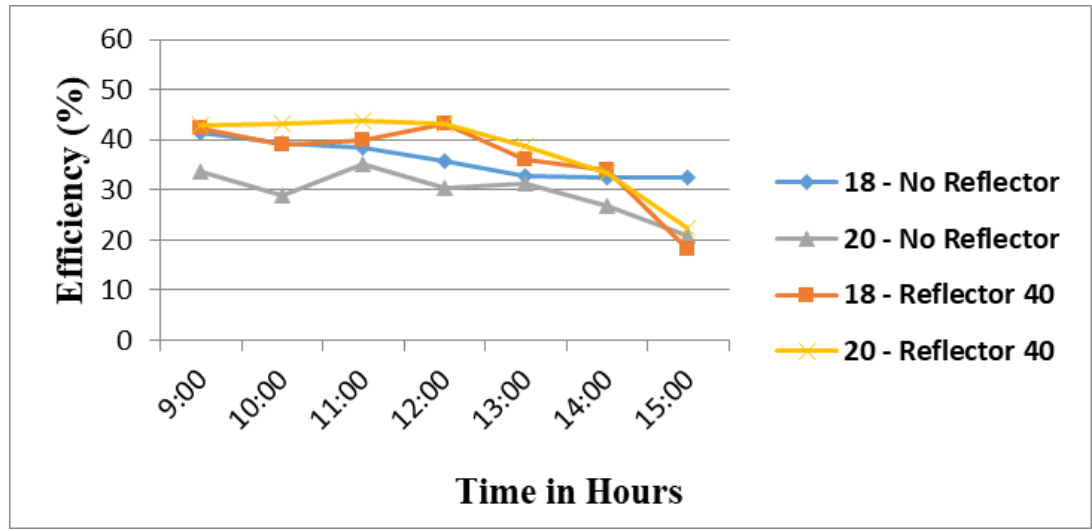

Figure 7. Collector efficiency with variation of flow rate and reflector

TABLE 1.

QU AND EFFICIENCY WITH TWO VARIATION OF MASS FLOW

\begin{tabular}{|c|c|c|c|c|c|c|c|c|}
\hline Time & \multicolumn{4}{|c|}{ Qu (Watt) } & \multicolumn{4}{|c|}{ Efficiency (\%) } \\
\hline 09:00 & 127,489 & 105,760 & 158,834 & 158,626 & 41,37 & 33,66 & 42,28 & 42,80 \\
\hline $10: 00$ & 142,107 & 110,349 & 160,921 & 177,006 & 39,20 & 28,99 & 39,16 & 43,08 \\
\hline 11:00 & 144,191 & 147,123 & 177,635 & 197,682 & 38,49 & 35,29 & 39,91 & 43,91 \\
\hline 14:00 & 94,041 & 78,163 & 117,027 & 117,236 & 32,42 & 26,95 & 33,98 & 33,35 \\
\hline $15: 00$ & 62,697 & 41,383 & 39,709 & 52,876 & 32,42 & 20,75 & 18,25 & 22,34 \\
\hline
\end{tabular}




\section{ACKNOWLEDGEMENT}

The author would like to thank the parties related to this research and also to the location of the research at the Solar Energy Laboratory, Department of Mechanical Engineering, Sepuluh Nopember Institute of Technology.

\section{REFERENCES}

[1] K. Li, T. Li, H. Tao, Y. Pan, and J. Zhang, "Numerical investigation of flow and heat transfer performance of solar water heater with elliptical collector tube,” Energy Procedia, vol. 70, pp. 285-292, May 2015.

[2] S. Jaisankar, J. Ananth, S. Thulasi, S. T. Jayasuthakar, and K. N. Sheeba, "A comprehensive review on solar water heaters," Renew. Sustain. Energy Rev., vol. 15, no. 6, pp. 3045-3050, Aug. 2011.
[3] H. Pandya and A. K. Behura, "Experimental study of V-through solar water heater for tilt angle and glass transmissivity,” Energy Procedia, vol. 109, pp. 377-384, Mar. 2017.

[4] S. Sutrisno and M. Mustafa, "Analisis kolektor sederhana bergelombang dengan penambahan reflektor terhadap jinerja solar water heater,” J. Agri-Tek, vol. 15, no. 2, pp. 86-93, Jan. 2014.

[5] H. Tanaka, "Solar thermal collector augmented by flat plate booster reflector: Optimum inclination of collector and reflector," Appl. Energy, vol. 88, no. 4, pp. 1395-1404, Apr. 2011.

[6] K. K. Chong, K. G. Chay, and K. H. Chin, "Study of a solar water heater using stationary V-trough collector,” Renew. Energy, vol. 39, no. 1, pp. 207-215, Mar. 2012.

[7] L. T. Kostić and Z. T. Pavlović, "Optimal position of flat plate reflectors of solar thermal collector," Energy Build., vol. 45, pp. 161-168, Feb. 2012.

[8] H. Bhowmik and R. Amin, "Efficiency improvement of flat plate solar collector using reflector," Energy Reports, vol. 3, pp. 119123, Nov. 2017. 